\title{
DISTRIBUTION AND ESTIMATION OF HEAVY METAL (Pb) CONTAMINATION LEVELS IN THE WATER AND SEDIMENT BONDET ESTUARY, CIREBON
}

\author{
Sri Wahyuningsih ${ }^{1}$ - Feti Fatimatuzzahroh ${ }^{2} \cdot$ Arbi Mei \\ Gitarama $^{3}$
}

Ringkasan The water and sediment caused by heavy metal has become a major problem in coastal areas. Heavy metals released into the water binds to particulate matter, accumulate into sediments and its predicted by the pollution assessment method. The aims of this research was to investigate the distribution and contamination levels of $\mathrm{Pb}$ in water and sediments of Bondet Estuary. Water and sediments samples were collected from four stations of Bondet Estuary in September 2020. The monitoring data of water quality status, contamination factor (CF), and geo accumulation index (Igeo) were used to provide a assessment of the $\mathrm{Pb}$ contamination. The concentration of $\mathrm{Pb}$ in water at all stations $(0,024-0,031 \mathrm{mg} / \mathrm{L})$ was higher than the standard surface water, with the status is lightly polluted (class $B$ ). $C F$ index for all stations $1<C F<3$ indicates moderate Pb contamination in the sediment, while Igeo

1) Program Studi Nautika, Akademi Maritim Cirebon (AMC), Jalan Dukuh Semar No. 1 Harjamukti Cirebon, Indonesia ${ }^{2}$ ) Fakultas Teknologi Kelautan dan Ilmu Perikanan, Universitas Nahdlatul Ulama (UNU) Cirebon, Jalan Dr. Cipto Mangunkusumo No. $288 \mathrm{Ci}$ rebon, Indonesia ${ }^{3}$ )Institut Teknologi dan Sains Nahdlatul Ulama Losarang

E-mail: syuni0389@gmail.com for each station is $<0$, which means no contamination. Overall when referring to some guidelines for sediment standards, Pb concentrations at all stations were still below the standard value for sediment. This study provides a basis for assessing future conditions and risks, so that it can contribute to the management and evaluation of heavy metal contamination in the Bondet Estuary.

Keywords Heavy metal, contamination factor, geo-accumulation index, Bondet River

\section{PENDAHULUAN}

Pertumbuhan populasi dan perkembangan industri telah sangat mempengaruhi beban pencemaran di lingkungan pesisir (Arifin et al., 2012). Kawasan pesisir menjadi ekosistem yang paling rentan terhadap perubahan. Hal ini dikarenakan pesisir menjadi perangkap dan penyaring bahan alami dan polutan antropogenik. Kontaminan beracun seperti logam dan polutan organik merupakan bagian dari produk komersial dan proses industri yang dibuang secara langsung ke sungai dan terbawa sampai perairan pesisir (Gao et al., 2014). Ting- 
kat pencemaran meningkat secara signifikan seiring dengan meningkatnya limbah industri dan limbah domestik yang masuk ke perairan (Jose et al., 2011; Anas, 2012).

Pencemaran logam berat di pesisir telah menjadi permasalahan penting di sejumlah negara, termasuk di Indonesia (Arifin et al., 2012). Kontaminasi logam berat yang parah di kawasan pesisir sebagian besar tercatat ada di Pesisir Utara Pulau Jawa dan Timur Sumatera, sementara perairan Pesisir Kalimantan dan Kepulauan Sulawesi secara umum relatif masih alami (Arifin et al., 2012; Nindyapuspa and Ni am, 2017).

Muara Sungai Bondet menjadi salah satu kawasan pesisir di Kabupaten Cirebon yang banyak mendapat tekanan lingkungan akibat masukan limbah dari kegiatan industri, domestik, dan pertanian yang terbawa melalui aliran sungai. Tercatat ada 18 aliran sungai di Kabupaten Cirebon yang bermuara ke laut dan menjadi tempat pembuangan akhir bagi kegiatan manusia (Anas, 2012). Berdasarkan laporan Status Lingkungan Hidup Kabupaten Cirebon (SLHD) Tahun 2014, perusahaan yang telah memiliki instalasi pengolahan limbah cair tidak lebih dari $10 \%$, sementara sebagian besar lainnya langsung membuang limbah ke sungai. Hasil penelitian Sudirman and Husrin (2014) berdasarkan indeks pencemaran menunjukkan kondisi Pesisir Kabupaten Cirebon pada setiap lokasi pengambilan sampel dalam kondisi tercemar, termasuk Muara Bondet.

Logam berat adalah kelompok polutan yang memiliki signifikansi ekologis tinggi (Ghrefat and Yusuf, 2006; Khaled et al., 2006), efek toksik, akumu- latif di perairan (Pan and Wang, 2012; Hu et al., 2013; Gotze et al., 2014), dan biokonsentrasi melalui rantai makanan (Gotze et al., 2014; Rahmanpour et al., 2014; Benson et al., 2017). Tidak seperti polutan organik yang dapat terdegradasi menjadi komponen yang kurang berbahaya melalui proses biologi atau kimia, logam berat dianggap sebagai polutan yang tidak dapat terdegradasi (Pan and Wang, 2012; Silambarasan et al., 2012). Logam berat tidak dapat dihilangkan dari air dengan pemurnian diri, tetapi terakumulasi dalam partikulat tersuspensi dan sedimen, kemudian melalui proses jaring makanan akan diserap oleh konsumen yang lebih tinggi (Ghrefat and Yusuf, 2006; Khaled et al., 2006; Cevik et al., 2009; Sun et al., 2011). Kontaminan ini menimbulkan ancaman serius terhadap ekosistem pesisir, laut dan masyarakat, mengakibatkan perubahan struktur dan fungsi ekosistem, eutrofikasi, penurunan hasil perikanan, kerugian ekonomi besar (Huang et al., 2013; Gao et al., 2014), menyebabkan efek toksik baik lethal maupun sub lethal, bahkan karsinogenik pada manusia yang mengkonsumsi organisme yang terpapar logam berat (Suprapti et al., 2016).

Setelah masuk ke perairan, logam berat yang terlarut dalam air akan terakumulasi dalam sedimen (Noegrohati, 2005; Passos et al., 2011; Wulan et al., 2013), atau dapat terlepas kembali ke kolom perairan tergantung kondisi fisika, kimia dan biologi perairan (Sitorus, 2004; Davutluoglu et al., 2011; Silva et al., 2017). Pengukuran logam berat dalam sedimen memberikan indikator yang lebih baik daripada bentuk terlarut. Konsentrasi logam berat dalam sedimen relatif stabil dan dapat meningkat, semen- 
tara konsentrasi logam berat di air sangat fluktuatif, sehingga sulit untuk menilai tingkat pencemaran logam di area yang luas (Arifin et al., 2012).

Toksisitas dari logam berat tergantung pada jenis logam, bioavailibilitas, tingkat penyerapan organisme, akumulasi di dalam tubuh dan tingkat ekskresi (Gotze et al., 2014). Hasil penelitian Silva et al. (2017) menunjukkan bahwa logam berat $\mathrm{Pb}$ memiliki bioavaibilitas paling rendah dibanding dengan logam lain seperti $\mathrm{Zn}, \mathrm{Cr}, \mathrm{Cu}$ dan $\mathrm{Cd}$, sehingga potensi akumulasi dalam sedimen lebih besar. Beberapa penelitian lain juga dilakukan untuk mengukur tingkat pencemaran logam berat dalam sedimen (Ghrefat and Yusuf, 2006; Khaled et al., 2006; Chen et al., 2007; Cevik et al., 2009; Vukovic et al., 2011; Permanawati et al., 2016; Bhuyan et al., 2017; Xu et al., 2017; Chen et al., 2019; Cui et al., 2019; Hoang et al., 2020; Islam et al., 2020).

Beberapa penelitian tersebut menunjukkan bahwa kajian mengenai sebaran logam berat di pesisir penting untuk dilakukan, karena tidak hanya terkait dengan kondisi fisik dan biologi lingkungan saja, tetapi kondisi tersebut juga mempengaruhi pertumbuhan ekonomi. Tujuan dari penelitian ini adalah untuk menilai status kontaminasi logam berat $\mathrm{Pb}$ pada air dan sedimen Muara Sungai Bondet Cirebon. Selain itu, kajian mengenai cemaran logam berat di pesisir juga diperlukan sebagai latar belakang informasi untuk membuat kebijakan terkait dengan perlindungan lingkungan pesisir.

\section{MATERI DAN METODE}

Muara Sungai Bondet merupakan salah satu kawasan pesisir yang terletak di Desa Sambeng Kecamatan Gunungjati Kabupaten Cirebon. Hasil pengukuran oleh SLHD Kabupaten Cirebon Tahun 2014 terhadap panjang Sungai Bondet yaitu $5200 \mathrm{~m}$, dengan lebar dasar 37,5 $\mathrm{m}$ dan lebar atas 44,5 m. Adapun beberapa kegiatan yang limbahnya dibuang di sepanjang aliran sungai sampai muara diantaranya berasal dari kegiatan industri, domestik, pertanian, penangkapan ikan, budidaya kerang dan pengolahannya.

Empat titik lokasi pengambilan sampel air dan sedimen (dinyatakan sebagai stasiun 1 , stasiun 2 , stasiun 3, dan stasiun 4) untuk mengevaluasi kontaminasi logam berat di Muara Sungai Bondet. Stasiun 1 merupakan perairan sebelum tempat perahu-perahu nelayan bersandar, stasiun 2 merupakan perairan dekat pemukiman dan perahu bersandar, stasiun 3 merupakan perairan dekat dengan tempat pelelangan ikan (TPI) Bondet mendekati muara, dengan banyak perahu bersandar, dan stasiun 4 merupakan perairan sekitar muara mendekati laut. Penelitian dilakukan menggunakan metode survei, dengan penentuan lokasi pengambilan sampel berdasarkan metode purposive sampling. Pengambilan sampel air dan sedimen dilakukan pada saat surut secara komposit. Lokasi pengambilan sampel disajikan dalam Gambar 1.

Sebanyak 12 sampel air permukaan dan 12 sampel sedimen dikumpulkan pada September 2020. Sampel air diambil dengan menggunakan Van Dorn Water Sampler, dan disimpan dalam botol amber, kemudian ditambahkan la- 


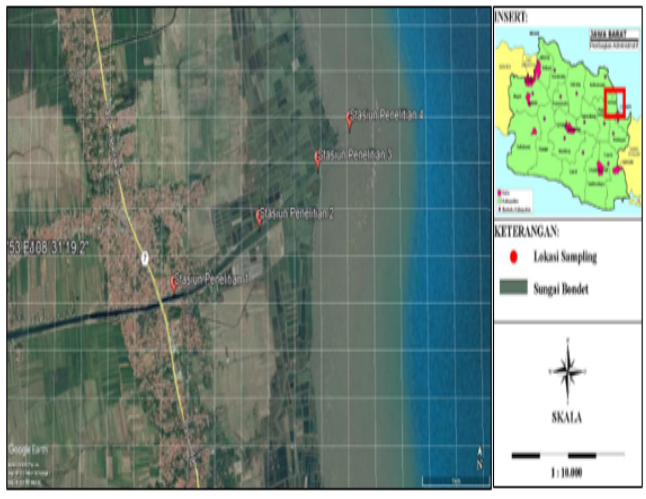

Gambar 1 Stasiun pengambilan sampel

rutan $\mathrm{HNO}_{3}$ sebanyak $2 \mathrm{~mL}$ Sementara untuk pengambilan sampel sedimen menggunakan Eckman Grab dan disimpan dalam plastik. Semua sampel tersebut kemudian disimpan pada suhu $4^{\circ} \mathrm{C}$ sampai analisis di Laboratorium Produktivitas Lingkungan Fakultas Perikanan Kelautan IPB Bogor dengan menggunakan metode Atomic Absorption Spectrophotometry (AAS). Prosedur pengambilan dan analisis sampel dirujuk dari pedoman pengambilan sampel air permukaan (APHA, $23^{\text {nd }}$ Edition, 3030-B,3113-B, 2017), dan pedoman pengambilan sampel sedimen (APHA, $23^{\text {rd }}$ Edition, 3111-B, 3030-H, 2017) dari American Public Health Association (APHA).

Metode penentuan status mutu air dapat dihitung dengan menggunakan metode Storet berdasarkan skor dalam KMNLH No. 115 Tahun 2003 (Table 1). Penentuan status mutu air menggunakan metode Storet adalah dengan membandingkan data pengukuran dan baku mutu air yang sesuai dengan peruntukannya. Jika hasil pengukuran memenuhi nilai ambang batas (NAB) air (hasil pengukuran $<$ baku mutu) maka diberi skor 0 . Jika hasil pengukuran tidak memenuhi NAB (hasil pengukuran > baku mutu), diberi skor -1 sampai
Tabel 1 Penentuan Sistem nilai untuk menentukan status mutu air

\begin{tabular}{lcccc}
\hline Jumlah & \multirow{2}{*}{ Nilai } & \multicolumn{3}{c}{ Parameter } \\
\cline { 3 - 5 } & & Fisika & Kimia & Biologi \\
\hline \multirow{3}{*}{$<10$} & Maksimum & -1 & -2 & -3 \\
& Minimum & -1 & -2 & -3 \\
& Rata-rata & -3 & -6 & -9 \\
& Maksimum & -2 & -4 & -6 \\
$\geq 10$ & Minimum & -2 & -4 & -6 \\
& Rata-rata & -6 & -12 & -18 \\
\hline
\end{tabular}

dengan -31 sesuai dengan kalisifikasi mutu air (Gerhanae and Permanawati, 2016; Permanawati et al., 2016).

Penentuan status mutu air dengan menggunakan sistem nilai dari US-EPA ( $E n-$ vironmental Protection Agency) dengan mengklasifikasikan mutu air dalam empat kelas, yaitu:

1. $0=$ memenuhi baku mutu (Kelas A)

2. $-1 \mathrm{~s} / \mathrm{d}-10=$ tercemar ringan $($ Kelas B)

3. $-11 \mathrm{~s} / \mathrm{d}-30=$ tercemar sedang $(\mathrm{Ke}-$ las C)

4. $\geq-31=$ tercemar berat $($ Kelas D)

Faktor kontaminasi (CF) digunakan untuk menggambarkan kondisi kontaminasi logam berat pada sedimen di suatu perairan. CF pertama kali diperkenalkan oleh Hakanson (1980), dan dihitung berdasarkan rasio konsentrasi logam berat di lingkungan dan nilai referensi. $\mathrm{CF}$ dihitung berdasarkan persamaan berikut (Mulyaningsih et al., 2012; Ahmad, 2013; Hidayati et al., 2014; Mulyaningsih and Suprapti, 2016; Yona et al., 2018; Hoang et al., 2020).

$C F=\frac{C_{s i}}{C_{b i}}$

Dimana $\mathrm{C}_{s i}$ adalah konsentrasi logam berat sampel yang terukur pada sedimen, sementara $\mathrm{C}_{b i}$ adalah konsentrasi logam background, yang merupakan konsentrasi logam yang secara ala- 
mi ada dalam kerak bumi. Dalam penelitian ini, konsentrasi $\mathrm{Pb}$ background mengacu pada Mohiuddin et al. (2010) yaitu $12,5 \mathrm{mg} / \mathrm{kg}$.

Interpretasi nilai $\mathrm{CF}$ berdasarkan referensi dari Hakanson (1980), dimana nilai $\mathrm{CF}<1$ menunjukkan tingkat kontaminasi rendah, $1 \leq \mathrm{CF}<3$ menunjukkan tingkat kontaminasi sedang, $3 \leq \mathrm{CF}$ $<6$ menunjukkan tingkat kontaminasi tinggi, dan $\mathrm{CF}>6$ menunjukkan tingkat kontaminasi sangat tinggi.

Indeks Geoakumulasi (Igeo) digunakan untuk menilai tingkat pencemaran logam berat pada sedimen di suatu lingkungan. Igeo dihitung dengan mengalikan background value dengan sebuah bilangan (konstanta) 1,5 sebagai faktor koreksi matriks background akibat efek litogenik (proses pembentukan batubatuan). Nilai Igeo dihitung dengan menggunakan persamaan berikut (Ghrefat and Yusuf, 2006; Khaled et al., 2006; Chen et al., 2007; Cevik et al., 2009; Mulyaningsih et al., 2012; Ahmad, 2013; Zahra et al., 2014; Mulyaningsih and Suprapti, 2016; Yona et al., 2018; Pa et al., 2019; Hoang et al., 2020).

$I_{\text {geo }}=\log 2 \frac{\mathrm{Cn}}{1.5 \times \mathrm{Bn}}$

Dimana $\mathrm{Cn}$ adalah konsentrasi terukur logam berat $\mathrm{n}$ dalam sedimen, dan $\mathrm{Bn}$ merupakan konsentrasi background geokimia untuk logam berat $\mathrm{n}$ yang dapat diukur secara langsung dalam sedimen sebelum ada industri di area tersebut atau diambil dari literatur. Nilai $b a c$ kground yang digunakan untuk mendapatkan nilai Igeo dalam penelitian ini mengacu pada Turekian and Wedepohl (1961) yaitu untuk Pb 20 mg/kg.

Interpretasi nilai Igeo mengacu pada $\mathrm{Mu}-$ ller (1979), dimana kelas 0 (praktis tidak tercemar); Igeo $<0$ menunjukkan tidak terkontaminasi hingga terkontaminasi sedang (kelas 0); $0<$ Igeo $<1$; terkontaminasi sedang (kelas 1 ); $1<$ Igeo $<2$ terkontaminasi sedang hingga berat (kelas 2); $2<$ I geo $<3$ terkontaminasi cukup parah (kelas 3); $3<$ Igeo $<4$ terkotaminasi parah (kelas 4); $4<$ Igeo $<5$ terkontaminasi luar biasa parah (kelas 5); Igeo $>5$ tercemar sangat luar biasa parah (kelas 6).

Data kandungan logam berat $\mathrm{Pb}$ yang diperoleh dilakukan uji ANOVA untuk mengetahui perbedaan kandungan logam berat antar stasiun pada air dan sedimen, kemudian dilakukan uji lanjut Duncan 5\% untuk semua hasil. Analisis statistik data dilakukan dengan menggunakan paket perangkat lunak statistik SPSS.

\section{HASIL DAN PEMBAHASAN}

Hasil uji Anova menunjukkan konsentrasi $\mathrm{Pb}$ pada air di setiap stasiun menunjukkan hasil berbeda nyata $(\mathrm{P}<0,05)$. Hasil pengelompokkan menunjukkan bahwa konsentrasi $\mathrm{Pb}$ di stasiun 1 memiliki perbedaan nyata dengan stasiun 2 dan 3, namun tidak memiliki perbedaan nyata dengan stasiun 4. Hasil pengukuran konsentrasi $\mathrm{Pb}$ dan perbedaan setiap stasiun disajikan dalam Gambar 2 .

Secara umum logam $\mathrm{Pb}$ pada sampel air yang diukur memiliki konsentrasi antara 0,024-0,031 mg/L. Konsentrasi tertinggi ada di stasiun 2 yang dianggap memiliki banyak aktivitas masyarakat di sekitarnya. Tingginya konsentrasi logam $\mathrm{Pb}$ di stasiun 2 diduga dipengaruhi oleh kegiatan lalu lintas dan sandar perahu nelayan, sehingga menyebabkan banyaknya ceceran bahan bakar di sekitar perairan. Selain itu stasiun ini merupakan lokasi yang paling 


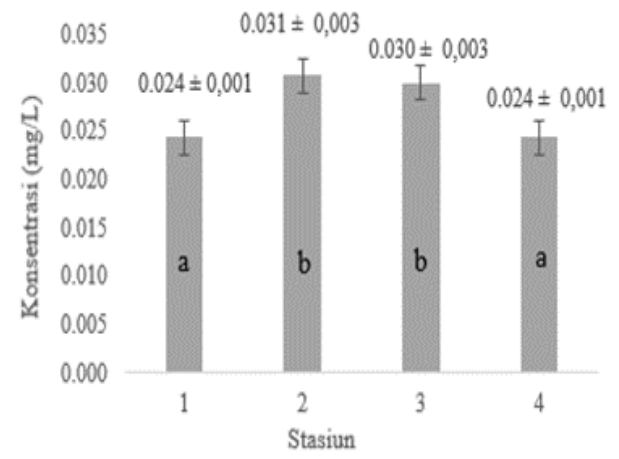

Gambar 2 Distribusi logam $\mathrm{Pb}$ dalam air (keterangan:* Huruf yang berbeda menunjukkan hasil yang berbeda nyata $(\mathrm{P}<0,05))$

berdekatan dengan pemukiman, sehingga berakibat pada tingginya masukan limbah domestik di sekitar peraian, hal ini terlihat dari banyaknya tumpukan sampah di stasiun 2. Hal ini sesuai dengan Permanawati et al. (2016), bahwa sumber pencemaran logam berat khususnya unsur $\mathrm{Pb}$ sebagian berasal dari limbah industri, rumah tangga, dan tumpahan atau bocoran bahan bakar perahu.

Konsentrasi $\mathrm{Pb}$ terendah terdapat di stasiun 1 dan 4, yang merupakan wilayah perairan dengan sedikit aktivitas. Stasiun 1 merupakan lokasi perairan yang cukup jauh dari kegiatan masyarakat seperti lalu lintas dan sandar perahu. Hal ini sesuai dengan Ahmed et al. (2017), bahwa rendahnya konsentrasi logam berat di perairan salah satunya dikarenakan tidak ada sumber antropogenik logam seperti ceceran bahan bakar yang mengandung timbal. Sementara pada stasiun 4, rendahnya konsentrasi $\mathrm{Pb}$ diduga disebabkan arus dan gelombang yang kuat, sehingga menyebabkan pergerakan dan pencampuran massa air. Menurut Sagala et al. (2014) distribusi penyebaran logam berat dipengaruhi oleh sirkulasi arus permukaan akibat topografi dan pola angin.
Rata-rata konsentrasi $\mathrm{Pb}$ dalam air $(0,024-$ $0,031 \mathrm{mg} / \mathrm{L}$ ) di semua stasiun telah melebihi nilai ambang batas yang ditetapkan oleh KMNLH No. 51 Tahun 2004, tentang batas maksimal cemaran logam $\mathrm{Pb}$ dalam air yaitu sebesar $0,008 \mathrm{mg} / \mathrm{L}$. Dengan demikian perairan Muara Sungai Bondet sudah tercemar logam $\mathrm{Pb}$.

Konsentrasi $\mathrm{Pb}$ pada penelitian ini $(0,024-$ $0,031 \mathrm{mg} / \mathrm{L}$ ) lebih besar jika dibandingkan Perairan Teluk Jakarta yaitu 0,005 0,011 mg/L (Permanawati et al. 2013), Perairan Pantai Timur Pulau Rote yaitu $<0,001-0,017 \mathrm{mg} / \mathrm{L}$ (Gerhanae and Permanawati (2016)), Pulau Kabaena yaitu <0,001-0,006 mg/L (Ahmad, 2010), dan hasil penelitian Sagala et al. (2014) $(<0,005 \mathrm{mg} / \mathrm{L})$ di perairan Laut Natuna yang masih alami dan belum tercemar logam $\mathrm{Pb}$. Namun konsentrasi $\mathrm{Pb}$ pada penelitian ini lebih rendah dibandingkan penelitian sebelumnya yang telah dilakukan di Perairan Bondet pada musim panas, dengan konsentrasi 0,04 \pm 0,07 mg/L (Nurhayati and Putri, 2019), dan di Perairan Segara Anakan, Cilacap 0,12-0,24 mg/L (Hidayati et al., 2014).

Hasil uji Anova menunjukan bahwa konsentrasi $\mathrm{Pb}$ di setiap stasiun menunjukkan hasil berbeda nyata, dengan nilai signifikansi 0,03 $(\mathrm{P}<0,05)$. Hasil uji lanjut Duncan menunjukkan bahwa konsentrasi $\mathrm{Pb}$ di setiap stasiun berbeda nyata, kecuali stasiun 1 dan stasiun 4 yang menunjukkan hasil tidak berbeda nyata. Hasil pengukuran dan analisis $\mathrm{Pb}$ disajikan dalam Gambar 3.

Rata-rata konsentrasi $\mathrm{Pb}$ dalam sedimen pada penelitian ini memiliki konsentrasi lebih besar dibandingkan konsentrasi $\mathrm{Pb}$ pada air. Hidayati et al. (2014) menyatakan bahwa logam berat cenderung membentuk kompleks dengan par- 


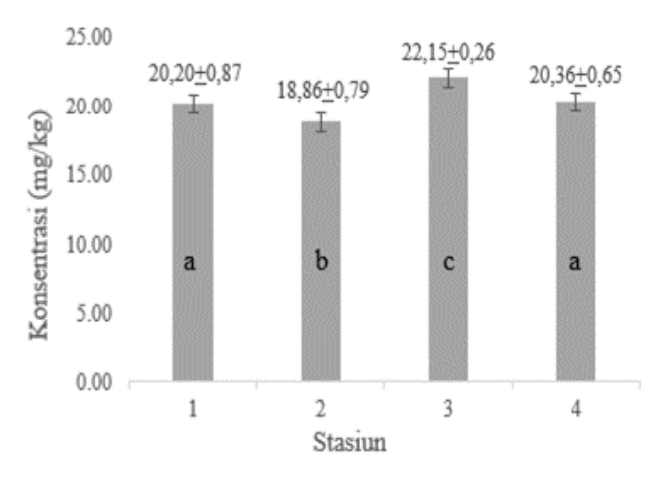

Gambar 3 Distribusi logam Pb di sedimen (keterangan:* Huruf yang berbeda menunjukkan hasil yang berbeda nyata $(\mathrm{P}<0,05))$

tikel di kolom perairan, kemudian mengendap dan terakumulasi dalam sedimen. Hal ini menyebabkan logam berat dalam sedimen cenderung memiliki konsentrasi lebih tinggi dibandingkan yang terlarut dalam air. Logam berat yang dilepaskan ke perairan akan mengikat materi partikulat, dan sedimen bertindak sebagai penyerap utama logam berat. Oleh karena itu logam berat cenderung terakumulasi dalam sedimen (Ahmed et al., 2017; Hoang et al., 2020).

Logam $\mathrm{Pb}$ dalam sedimen memiliki konsentrasi yang relatif bervariasi dengan kisaran antara 18,86-22,25 mg/L, dimana konsentrasi $\mathrm{Pb}$ tertinggi ada di stasiun $3(22,25 \mathrm{mg} / \mathrm{L})$, dan konsentrasi terendah di stasiun 2. Kondisi ini menunjukkan konsentrasi $\mathrm{Pb}$ dalam sedimen tidak memiliki pola yang sama seperti di permukaan air. Tingginya konsentrasi $\mathrm{Pb}$ di stasiun 3 selain karena adanya masukan dari sejumlah besar limbah pertanian, industri, dan pemukiman dari hulu sungai, juga diduga disebabkan oleh padatnya aktivitas sandar perahu, dan bongkar muat ikan. Hal ini dikarenakan stasiun 3 merupakan perairan yang paling beredekatan dengan TPI Bondet. Stasiun 3 menjadi jalur transportasi yang padat bagi perahu nelay- an, sehingga menyebabkan banyaknya tumpahan dan ceceran bahan bakar di sekitar lokasi perairan. Hal serupa disampaikan oleh Ahmed et.al (2017) bahwa logam $\mathrm{Pb}$ termasuk logam antropogenik yang khas dan keberadaanya di perairan dipengaruhi oleh limpasan permukaan dan masukan limbah organik dari limbah kota dan limbah padat. Selain itu, sumber antropogenik logam $\mathrm{Pb}$ berasal dari aktivitas transportasi yang menggunakan bahan bakar. Menurut Mohiuddin et al. (2010), logam Pb dapat dijadikan sebagai indikator yang baik untuk pencemaran, terutama yang berasal dari penggunaan bahan bakar yang mengandung timbal.

Konsentrasi $\mathrm{Pb}$ terendah di stasiun 2 $(18,86 \mathrm{mg} / \mathrm{L})$ menunjukkan rendahnya tingkat akumulasi $\mathrm{Pb}$ dalam sedimen, meskipun pada stasiun 2 ini merupakan jalur transportasi perahu nelayan dan dekat dengan pemukiman. Kondisi demikian diduga karena rendahnya kapasitas sedimen dalam deposisi partikel logam. Menurut Zhuang et al. (2018), konsentrasi logam berat dalam sedimen dipengaruhi oleh kemampuan sedimen dalam adsorpsi permukaan partikel, pertukaran ion, pengendapan, dan kompleksasi dengan bahan organik. Rendahnya konsentrasi $\mathrm{Pb}$ di stasiun 2 dibandingkan dengan stasiun lainnya juga diduga dipengaruhi oleh pelepasan kembali logam dari sedimen ke kolom perairan, hal ini ditunjukkan dengan tingginya kosentrasi $\mathrm{Pb}$ dalam sampel air, meskipun hal tersebut tidak selalu ditunjukkan dengan pola yang sama. Beberapa logam yang terikat sedimen dapat dilepaskan ke kolom air melalui resuspensi sedimen, reaksi desorpsi, reaksi reduksi atau oksidasi tergantung kondisi fisikokimia perairan (Davutluoglu 
et al., 2011; Silva et al., 2017; Zhuang et al., 2018).

Konsentrasi $\mathrm{Pb}$ dalam sedimen di perairan daerah penelitian masih di bawah batas baku mutu sedimen berdasarkan Sediment Quality Standards, WAC 172204-320 yaitu 450 mg/kg (Permanawati et al., 2016). Sementara KMNLH (2010) menetapkan nilai ambang batas untuk $\mathrm{Pb}$ dalam sedimen yang aman bagi kehidupan organisme akuatik adalah 36,8 $\mathrm{mg} / \mathrm{kg}$. Dengan demikian konsentrasi logam $\mathrm{Pb}$ dalam sedimen pada penelitian ini masih aman untuk kehidupan organisme perairan. Demikian pula jika mengacu pada pedoman mutu sedimen Australian and New Zealand Environment and Conservation Council (ANZECC) dan Resource Management Council of Australia and New Zealand (ANZECC, 2000)yaitu sebesar $50 \mathrm{mg} / \mathrm{kg}$, dan Canadian Council of Ministry of Environment (Ministers of the Environment, 2002) sebesar 30,2 mg/kg, maka konsentrasi $\mathrm{Pb}$ dalam sedimen di Muara Sungai Bondet ini masih aman.

Konsentrasi $\mathrm{Pb}$ dalam sedimen pada penelitian ini $(18,86-22,25 \mathrm{mg} / \mathrm{kg})$ lebih rendah jika dibandingkan di Perairan Teluk Jakarta yaitu 14-58,10 mg/kg (Permanawati et al., 2016), Muara Sungai Way Kuala Bandar Lampung yaitu 140,37201,31 mg/kg (Hidayat, 2012), Sungai di Lokasi Penambangan Emas Tradisional, Desa Boto, Kecamatan Jatiroto yaitu 9-508 $\mathrm{mg} / \mathrm{kg}$ (Pa et al., 2019). Sementara rata-rata konsentrasi $\mathrm{Pb}$ dalam sedimen Muara Sungai Bondet lebih besar jika dibandingkan di Perairan Segara Anakan, Cilacap yaitu 3,9621,99 mg/kg (Hidayati et al., 2014), Perairan Pulau Bangka yaitu 1,682-16,516 $\mathrm{mg} / \mathrm{kg}$ (Ahmad, 2013), DAS Ciujung, Banten yaitu 15,87-19,14 mg/kg (Mu-
Tabel 2 Hasil perhitungan kontaminasi logam $\mathrm{Pb}$ dalam air dan sedimen

\begin{tabular}{cccc}
\hline \multirow{3}{*}{ Stasiun } & \multicolumn{3}{c}{ Indeks } \\
\cline { 2 - 4 } & Air & Sedimen \\
\cline { 2 - 4 } & Status Mutu Air & CF & Igeo \\
\hline 1 & -10 & 1,62 & $-0,57$ \\
2 & -10 & 1,51 & $-0,67$ \\
3 & -10 & 1,77 & $-0,44$ \\
4 & -10 & 1,63 & $-0,56$ \\
Rerata & -10 & 1,63 & $-0,56$ \\
\hline
\end{tabular}

lyaningsih et al., 2012), dan Perairan Pulau Muna, Kabaena, dan Buton, Sulawesi Tenggara yaitu $0,059-11,207 \mathrm{mg} / \mathrm{kg}$ (Ahmad, 2010).

Dalam penilaian tingkat kontaminasi logam berat di perairan, penting diketahui apakah logam berat yang diukur telah memenuhi atau melampaui baku mutu air. Metode Storet merupakan salah satu metode untuk menentukan status mutu air berdasarkan ketentuan dalam KMNLH No. 115 Tahun 2003. Sementara untuk memperkirakan tingkat kontaminasi sedimen dapat digunakan faktor kontaminasi (CF) dan Indeks geokumulasi (Igeo). Hasil perhitungan status mutu air, nilai CF dan Igeo disajikan dalam Tabel 2.

Berdasarkan skor penilaian status mutu air Muara Sungai Bondet menggunakan metode Storet, nilai status mutu air di semua stasiun adalah -10 (Tabel 2). Hal ini berarti kualitas air di perairan Muara Sungai Bondet termasuk kelas B (tercemar ringan). Data ini menggambarkan bahwa masukan logam $\mathrm{Pb}$ baik yang berasal dari proses alami (peluruhan mineral logam) dan limbah berbagai kegiatan di hulu sungai dan sekitar muara, belum memberikan pengaruh yang signifikan terhadap fluktuasi konsentrasi logam $\mathrm{Pb}$ di Muara Sungai Bondet.

Status mutu air berdasarkan konsentrasi logam Pb di Muara Sungai Bondet (- 
10) berada pada level lebih tinggi jika dibandingkan dengan status mutu air di Perairan Perairan Pantai Timur Pulau Rote yang termasuk kelas A (baik sekali), dengan skor 0 (Gerhanae and Permanawati, 2016). Sementara Perairan Teluk Jakarta, status mutu air berdasarkan logam $\mathrm{Pb}$ termasuk kelas $\mathrm{B}$ dengan kondisi tercemar ringan (skor -2) (Permanawati et al., 2016), sedangkan perairan Pulau Muna, Kabena dan Buton termasuk kelas A yang berarti kondisinya masih baik sekali, dengan skor penilaian adalah 0 (Ahmad, 2010).

Berdasarkan Tabel 2, dapat diketahui bahwa faktor kontaminasi (CF) dengan mengacu pada kriteria berdasarkan nilai yang ditetapkan oleh Hakanson (1980), maka seluruh stasiun pengambilan sampel memiliki $\mathrm{CF}$ antara $1 \leq \mathrm{CF}<3$ dengan rata-rata 1,63 . Hasil ini menunjukkan bahwa sedimen seluruh lokasi sampling terkontaminasi sedang oleh logam $\mathrm{Pb}$. Hasil serupa juga ditemukan di sedimen Perairan Pulau Bangka Selatan dan Timur yang menunjukkan nilai faktor kontaminasi oleh logam $\mathrm{Pb}$ $1<\mathrm{CF}<3$ di beberapa stasiun pengamatan (Ahmad, 2013). Sementara nilai faktor kontaminasi $<1$ terdapat di sedimen Perairan Segara Anakan, Cilacap (Hidayati et al., 2014), dan DAS Ciujung, Banten (Mulyaningsih et al., 2012), yang artinya rendahnya atau belum adanya kontaminasi logam $\mathrm{Pb}$ di kedua lokasi perairan tersebut.

Indeks geoakumulasi (Igeo) digunakan untuk pengukuran kuantitatif suatu logam berat dalam sampel sedimen. Tidak seperti data pemantauan, Igeo mempertimbangkan nilai logam berat latar (background) (Hoang et al., 2020). Hasil perhitungan Igeo logam $\mathrm{Pb}$ dalam penelitian ini menunjukkan nilai yang seragam di setiap stasiun pengambilan sampel, dengan rata-rata -0,56 (Igeo $<0)$ (Tabel 2). Hal ini menunjukkan bahwa sedimen Muara Sungai Bondet termasuk kelas 0 , yang berarti tidak terkontaminasi logam $\mathrm{Pb}$. Nilai Igeo $<0$ juga ditemukan di sedimen Perairan $\mathrm{Pu}$ lau Bangka Timur, Utara, dan Selatan (Ahmad, 2013), dan sepanjang Pantai Barat Perairan Selat Bali, Banyuwangi (Yona et al., 2018). Sementara di Sungai dekat lokasi penambangan emas tradisional, Desa Boto, Kecamatan Jatiroto menunjukkan nilai Igeo sedimen untuk logam $\mathrm{Pb}$ adalah $0<$ Igeo $<1$, yang berarti sungai di lokasi tersebut tidak terkontaminasi sampai terkontaminasi sedang (Pa et al., 2019). Kondisi serupa juga terjadi di DAS Ciujung, Banten, yang menunjukkan Igeo sedimen untuk $\mathrm{Pb}$ antara 0-1 (tidak terkontaminasi hingga terkontaminasi sedang) (Mulyaningsih et al., 2012).

\section{SIMPULAN}

Metode penilaian seperti Storet, CF, dan Igeo digunakan untuk menilai tingkat kontaminasi logam $\mathrm{Pb}$ di Muara Sungai Bondet. Studi lapangan menunjukkan bahwa konsentrasi logam $\mathrm{Pb}$ telah melebihi NAB untuk semua stasiun pengambilan sampel, dan termasuk kelas $\mathrm{B}$ (tercemar ringan) berdasarkan metode Storet. Sementara pendugaan kontaminasi sedimen berdasarkan metode $\mathrm{CF}$ dan Igeo, yaitu adanya kontaminasi sedang oleh logam $\mathrm{Pb}$ berdasarkan $\mathrm{CF}$, dan tidak terkontaminasi berdasarkan Igeo. Hasil interpretasi ini dapat saja dipengaruhi oleh penggunaan nilai $b a c$ kground yang berbeda untuk $\mathrm{CF}$ dan Igeo. 
Acknowledgements : Penelitian ini merupakan bagian dar Penelitian Dosen Pemula (PDP) tahun 20192020, yang didanai oleh Kemenristekdikti. Ucapan terima kasih diberikan kepada pihak Kemenristekdikti dan semua pihak yang telah terlibat dalam penelitian.

\section{Pustaka}

Ahmad, F. (2010). Tingkat pencemaran logam berat dalam air laut dan sedimen di perairan pulau muna, kabaena, dan buton sulawesi tenggara. Makara Journal of Science.

Ahmad, F. (2013). Distribution and prediction on heavy metals pollution level (pb, cd, cu, zn, and ni) in sediment in bangka island waters using load pollution index and geoaccumulation index. Jurnal Ilmu dan Teknologi Kelautan Tropis, 5(1).

Ahmed, M. M., Doumenq, P., Awaleh, M. O., Syakti, A. D., Asia, L., and Chiron, S. (2017). Levels and sources of heavy metals and pahs in sediment of djibouti-city (republic of djibouti). Marine pollution bulletin, 120(1-2):340-346.

Anas, P. (2012). Study on the interaction between fish stocks and fisherman poverty as a basis for coastal fisheries management in cirebon regency, province of west java. Master's thesis, IPB (Bogor Agricultural University).

ANZECC, A. (2000). Australian and new zealand guidelines for fresh and marine water quality. Technical report, Australian and New Zealand Environment and Conservation Council and Agriculture and Resource Management Council of Australia and New Zealand, Canberra.

Arifin, Z., Puspitasari, R., and Miyazaki, N. (2012). Heavy metal contamination in indonesian coastal marine ecosystems: A historical pers- pective. Coastal Marine Science, 35(1):227-233.

Benson, N. U., Anake, W. U., Essien, J. P., Enyong, P., and Olajire, A. A. (2017). Distribution and risk assessment of trace metals in leptodius exarata, surface water and sediments from douglas creek in the qua iboe estuary. Journal of Taibah University for Science, 11(3):434-449.

Bhuyan, M. S., Bakar, M. A., Akhtar, A., Hossain, M. B., Ali, M. M., and Islam, M. S. (2017). Heavy metal contamination in surface water and sediment of the meghna river, bangladesh. Environmental nanotechnology, monitoring \& management, 8:273-279.

Cevik, F., Goksu, M. Z. L., Derici, O. B., and Findik, O. (2009). An assessment of metal pollution in surface sediments of seyhan dam by using enrichment factor, geoaccumulation index and statistical analyses. Environmental monitoring and assessment, 152(1):309-317.

Chen, C.-W., Kao, C.-M., Chen, C.F., and Dong, C.-D. (2007). Distribution and accumulation of heavy metals in the sediments of kaohsiung harbor, taiwan. Chemosphere, 66(8):1431-1440.

Chen, M., Li, F., Tao, M., Hu, L., Shi, Y., and Liu, Y. (2019). Distribution and ecological risks of heavy metals in river sediments and overlying water in typical mining areas of china. Marine pollution bulletin, 146:893899.

Cui, S., Zhang, F., Hu, P., Hough, R., Fu, Q., Zhang, Z., An, L., Li, Y.-F., Li, K., Liu, D., et al. (2019). Heavy metals in sediment from the urban and rural rivers in harbin city, northeast china. International journal 
of environmental research and public health, 16(22):4313.

Davutluoglu, O. I., Seckin, G., Ersu, C. B., Yilmaz, T., and Sari, B. (2011). Heavy metal content and distribution in surface sediments of the seyhan river, turkey. Journal of environmental management, 92(9):2250-2259.

Gao, X., Zhou, F., and Chen, C.-T. A. (2014). Pollution status of the bohai sea: an overview of the environmental quality assessment related trace metals. Environment international, 62:12-30.

Gerhanae, N. Y. and Permanawati, Y. (2016). Kandungan logam berat (cd, $\mathrm{cu}, \mathrm{pb}$, dan zn) dalam air laut di perairan pantai timur pulau rote. Jurnal Geologi Kelautan, 13(2):99-107.

Ghrefat, H. and Yusuf, N. (2006). Assessing mn, fe, cu, zn, and cd pollution in bottom sediments of wadi al-arab dam, jordan. Chemosphere, 65(11):2114-2121.

Gotze, S., Bose, A., Sokolova, I. M., Abele, D., and Saborowski, R. (2014). The proteasomes of two marine decapod crustaceans, european lobster (homarus gammarus) and edible crab (cancer pagurus), are differently impaired by heavy metals. Comparative Biochemistry and Physiology Part C: Toxicology \& Pharmacology, 162:62-69.

Hakanson, L. (1980). An ecological risk index for aquatic pollution control. a sedimentological approach. Water research, 14(8):975-1001.

Hidayat, D. (2012). Kajian sebaran logam berat $\mathrm{pb}$ pada sedimen di muara sungai way kuala bandar lampung. Jurnal Sains MIPA Universitas Lampung, 17(3).
Hidayati, N. V., Siregar, A. S., Sari, L. K., and Putra, G. L. (2014). Pendugaan tingkat kontaminasi logam berat $\mathrm{pb}$, cd dan cr pada air dan sedimen di perairan segara anakan, cilacap. Omni-Akuatika, 10(1).

Hoang, H.-G., Lin, C., Tran, H.-T., Chiang, C.-F., Bui, X.-T., Cheruiyot, N. K., Shern, C.-C., and Lee, C.-W. (2020). Heavy metal contamination trends in surface water and sediments of a river in a highly-industrialized region. Environmental Technology \& Innovation, 20:101043.

Hu, B., Li, J., Zhao, J., Yang, J., Bai, F., and Dou, Y. (2013). Heavy metal in surface sediments of the liaodong bay, bohai sea: distribution, contamination, and sources. Environmental Monitoring and Assessment, 185(6):5071-5083.

Huang, L., Pu, X., Pan, J.-F., and Wang, B. (2013). Heavy metal pollution status in surface sediments of swan lake lagoon and rongcheng bay in the northern yellow sea. Chemosphere, 93(9):1957-1964.

Islam, M. A., Das, B., Quraishi, S. B., Khan, R., Naher, K., Hossain, S. M., Karmaker, S., Latif, S. A., and Hossen, M. B. (2020). Heavy metal contamination and ecological risk assessment in water and sediments of the halda river, bangladesh: A natural fish breeding ground. Marine Pollution Bulletin, 160:111649.

Jose, J., Giridhar, R., Anas, A., Bharathi, P. L., and Nair, S. (2011). Heavy metal pollution exerts reduction/adaptation in the diversity and enzyme expression profile of heterotrophic bacteria in cochin estuary, india. Environmental Pollution, 159(10):2775-2780. 
Khaled, A., El Nemr, A., and El Sikaily, A. (2006). An assessment of heavy-metal contamination in surface sediments of the suez gulf using geoaccumulation indexes and statistical analysis. Chemistry and Ecology, 22(3):239-252.

Ministers of the Environment, C. C. o. (2002). Canadian environmental quality guidelines, volume 2. Canadian Council of Ministers of the Environment.

Mohiuddin, K., Zakir, H., Otomo, K., Sharmin, S., and Shikazono, N. (2010). Geochemical distribution of trace metal pollutants in water and sediments of downstream of an urban river. International Journal of Environmental Science \& Technology, 7(1):17-28.

Muller, G. (1979). Schwermetalle in den sediments des rheinsveranderungen seit 1971, umsch.

Mulyaningsih, T. R., AlFian, A., and Sutisna, S. (2012). Distribusi logam berat dalam sedimen daerah aliran sungai ciujung banten. Jurnal Teknologi Reaktor Nuklir Tri Dasa Mega, 14(3):157-169.

Mulyaningsih, T. R. and Suprapti, S. (2016). Penaksiran kontaminasi logam berat dan kualitas sedimen sungai cimadur, banten. GANENDRA Majalah IPTEK Nuklir, 18(1):1121.

Nindyapuspa, A. and $\mathrm{Ni}$ am, A. C. (2017). Distribusi logam berat timbal di perairan laut kawasan pesisir gresik. Al-Ard: Jurnal Teknik Lingkungan, 3(1): 1 - 5 .

Noegrohati, S. (2005). Sorptiondesorption characteristics of heavy metals and their availability from the sediment of segara anakan estuary. Indonesian Journal of Chemis- try, 5(3):236-244.

Nurhayati, D. and Putri, D. A. (2019). Bioakumulasi logam berat pada kerang hijau (perna viridis) di perairan cirebon beradasarkan musim yang berbeda. Akuatika Indonesia, 4(1):6-10.

Pa, E. P. D., Budianta, W., and Putra, D. P. E. (2019). Kajian kandungan logam berat pada sedimen sungai di lokasi penambangan emas tradisional, desa boto, kecamatan jatiroto. PROMINE , 7(2):48-53.

Pan, K. and Wang, W.-X. (2012). Trace metal contamination in estuarine and coastal environments in china. Science of the total environment, 421:3-16.

Passos, E. d. A., Alves, J. d. P. H., Garcia, C. A. B., and Costa, A. C. S. (2011). Metal fractionation in sediments of the sergipe river, northeast, brazil. Journal of the Brazilian Chemical Society, 22:828-835.

Permanawati, Y., Zuraida, R., and Ibrahim, A. (2016). Kandungan logam berat (cu, pb, zn, cd, dan cr) dalam air dan sedimen di perairan teluk jakarta. Jurnal geologi kelautan, 11(1):9-15.

Rahmanpour, S., Ghorghani, N. F., and Ashtiyani, S. M. L. (2014). Heavy metal in water and aquatic organisms from different intertidal ecosystems, persian gulf. Environmental monitoring and assessment, 186(9):5401-5409.

Sagala, M., Bramawanto, R., Kuswardani, A., and Pranowo, W. S. (2014). Distribusi logam berat di perairan natuna distribution of heavy metals in natuna coastal waters. Jurnal Ilmu dan Teknologi Kelautan Tropis, 6(2):297-310. 
Silambarasan, K., Senthilkumaar, P., and Velmurugan, K. (2012). Studies on the distribution of heavy metal concentrations in river adyar, chennai, tamil nadu. European Journal of Experimental Biology, 2(6):21922198.

Silva, C. A. R. E., Fonseca, E. M., Grotto, B. W., Souza, F. E. D., and Baptista, J. A. (2017). Potentially mobile of heavy metals on the surface sediments in tropical hypersaline and positive estuaries. Anais da Academia Brasileira de Ciencias, 89:2597-2607.

Sitorus, H. (2004). Analisis beberapa karakteristik lingkungan perairan yang mempengaruhi akumulasi logam berat timbal dalam tubuh kerang darah di perairan pesisir timur sumatera utara. Jurnal Ilmu-ilmu Perairan dan Perikanan Indonesia, 11(1):53-60.

Sudirman, N. and Husrin, S. (2014). Status baku mutu air laut untuk kehidupan biota dan indeks pencemaran perairan di pesisir cirebon pada musim kemarau [water quality standards for marine life and pollution index in cirebon coastal area in the dry season]. Jurnal Ilmiah Perikanan dan Kelautan, 6(2):149-154.

Sun, J., Rong, J., Zheng, Y., Ma, D., and Lan, X. (2011). Risk assessment of heavy metal contaminated dagu river sediments. Procedia Environmental Sciences, 8:764-772.

Suprapti, N. H., Bambang, A. N., Swastawati, F., and Kurniasih, R. A. (2016). Removal of heavy metals from a contaminated green mussel [perna viridis (linneaus, 1758)] using acetic acid as chelating agents. Aquatic Procedia, 7:154-159.
Turekian, K. K. and Wedepohl, K. H. (1961). Distribution of the elements in some major units of the earth's crust. Geological society of America bulletin, 72(2):175-192.

Vukovic, Z., Radenkovic, M., Stankovic, S. J., and Vukovic, D. (2011). Distribution and accumulation of heavy metals in the water and sediments of the river sava. Journal of the Serbian Chemical Society, 76(5):795-803.

Wulan, S. P., Thamrin, and Amin, B. (2013). Konsentrasi, distribusi, dan korelasi logam berat pb, cr dan zn pada air dan sedimen di perairan sungai siak sekitar dermaga pt. indah kiat pulp and paper perawang propinsi riau. Technical report, Pusat Penelitian Lingkungan Hidup Universitas Riau.

Xu, F., Liu, Z., Cao, Y., Qiu, L., Feng, J., Xu, F., and Tian, X. (2017). Assessment of heavy metal contamination in urban river sediments in the jiaozhou bay catchment, qingdao, china. Catena, 150:9-16.

Yona, D., Sari, S. H. J., Kretarta, A., Putri, C. R., Effendy, M. N. A., and AsAdi, M. A. (2018). Distribusi dan status kontaminasi logam berat pada sedimen di sepanjang pantai barat perairan selat bali, banyuwangi.

Zahra, A., Hashmi, M. Z., Malik, R. N., and Ahmed, Z. (2014). Enrichment and geo accumulation of heavy metals and risk assessment of sediments of the kurang nallah feeding tributary of the rawal lake reservoir, pakistan. Science of the Total Environment, 470:925-933.

Zhuang, Q., Li, G., and Liu, Z. (2018). Distribution, source and pollution level of heavy metals in river sediments from south china. Catena, 
170:386-396.

Kontribusi: Wahyuningsih, S: Mengambil data Lapangan, analisis data, menulis manuscript; Fatimatuzzahroh, F:Membantu pengambilan data ; Gitarama, A. M: Mengambil data lapangan 